\title{
INTEGRATED INTER-ROW CULTIVATOR UNIT SUIT FOR VEGETABLE CROPS
}

\section{EL-Shabrawy T. H.*}

\section{ABSTRACT}

This research aimed manufactured and evaluate the developed cultivator unit with modified share suit for vegetables crops inter - row cultivation process, field experiments were carried out on tomato crop planting season 2019 under different operating conditions, at three types of shares used in cultivator unit St (shovel share \& Duck leg share \& modified share with wings), four inclination angles of soil sliding knife $\mathrm{Sa}$ $\left(\mathrm{Sa} 1=30^{\circ} \& \mathrm{Sa} 2=35^{\circ} \& \mathrm{Sa3}=40^{\circ} \& \mathrm{Sa} 4=45^{\circ}\right)$ and three depths of press wheel $W d(W d 1=2 \& W d 2=3$ and $W d 3=4 \mathrm{~cm}$.). four measurements achieved : weed erasing efficiency (We \%) ‘ weed control efficiency (Wc $\%)$ ' percentage of damaged plants ( $\mathrm{Dp} \%)$ and furrow cross-section profiles, all experimental procedures and measurements were assessed after 30 days from tomato transplanting. The results showed that the highest press wheel depth $(W d 3=4 \mathrm{~cm})$ with soil sliding knife inclined angle $\left(\mathrm{Sa}=45^{\circ}\right)$ and wing share obtained high erasing efficiency (We $=97 \%$ ) and highest weed control with regular forming furrow profile, on the other hand duck leg share had highest damage plant percentage $(\mathrm{D} p=1.2 \%)$.

Key words: Integrated weed control - Mechanical inter-row cultivation - Tomato crop cultivation - Furrow - Press wheel Cultivator share

\section{ITRODUCTION}

The cultivation process is an important process for all growing crops for the purpose of soil aeration and inter-row weeds control

1 and also the soil reconstruction and planting ridge forming. This study conducted on the constructed and performance a new simple integrated inter-row cultivator unit consists of two main units, the first one (modified share with ridge armors protection and soil sliding knife), the second (chassis with inter-row press wheel forming device) and achieved on one of the most important vegetable crops in Egypt is tomato

*Assoc. Prof., Agric. Eng. Dept., Agric. Fac. Mansoura Univ. 
crop that sensitive to the growth of weeds that is essential breadwinner of publishes serious viral diseases of the crop as the white fly. The aims of this work is to study and performance a local inter- row cultivator with protection ridge side wheel arm and modified share attached with interrow furrow press wheel.

Amonov, et. al. (2006) showed that, the proposed cultivator utilizes light torsion pivots with gauging beams and guiding slits to allow a reduction of the protected zone surrounding the plant by 2 to $2.5 \mathrm{~cm}$ and improves the soil surface condition (soil crumbling ability). Herbicide use and hand labor can be significantly reduced, which should lead to an increase in profit. Manuwa et. al. (2009) had a study to developed four L shape blades at row-crop power weeder with $0.24 \mathrm{~cm}$ cutting width its result showed that $95 \%$ weeding efficiency achieved with cutting blades rotational speed $800 \mathrm{rpm}$. From the other hand Rathod et. al (2010) done field tests for developed inter - row rotary weeder, the study conducted at three levels of forward speed $(1.1,1.2$ and $1.5 \mathrm{~km} / \mathrm{h}$ ) and $257 \mathrm{rpm} \mathrm{L}$ shape blades rotational speed, the result of this study was weeding efficiency $92.23 \%$ and field capacity 1.43 ha/day with field efficiency $86.34 \%$ developed weeder saved cost by $68.7 \%$. Srinivas et. al. (2008) evaluate the types of blades L shape, C shape and Sweep blade performance for inter-row cultivation process with sweet sorghum crop the results showed that the percentage of plant damage were $3.4 \%, 5.1 \%$ and $1.2 \%$ for blades respectively from the other side weeding efficiency 91\% obtained with L shape blades but loast value was $84 \%$ with $\mathrm{C}$ type share blades. Mahilang et. al. (2017) developed and tested operated power rotary weeder with cutting unit attached with 3 hubs with $2 \mathrm{~L}$ shape blades on rotary weeder shaft, the results told us that field capacity $0.14 \mathrm{ha} / \mathrm{h}$ and weeding efficiency with $60 \%$ field efficiency. Over the last fifteen years, use of herbicides had a bad effect on environmental and human health, increasing of herbicide resistance, the interest to develop new methods for weed control by mechanical ways to use alone or with herbicides in integrated weed control methods strategies Harker and O'Donovan (2013). Also Euro and Francesco (2014) evaluate the effects of chemical and mechanical methods (hoeing, spring-tine harrowing, hoeing-ridging, finger-weeding, split-hoeing, and herbicides) in inter- 
row cultivation, herbicides broadcast on weed control, weed seed rain and crop yield. The choice of chemical and mechanical treatments in maize and soyabean. The combination of herbicides intra-row cavity and inter-row mechanical cultivation gave best efficacy (on average $99 \%$ of weed control), with a 50\% reduction in the chemical also chemical method load in the environment. Hoeing cultivation-ridging gave good results, (93\% of weed control) required to be managed more carefully in order to maximize the weed control reducing yield losses. Pannacci and Tei (2014) focus on the control of weeds growing in the crop line intrarow, weeds cultivations, motivated by the fact that inter-row weeds, those growing between the crop rows, can be easily controlled by most interrow cultivators. Other study by Melander et. al. (2005) aimed to compare the weeding performance of an intelligent mechanical weeding cultivation machine with non-intelligent tools such as a weed shares, were it conducted two experiments in transplanted onion and in transplanted white cabbage.

A competition study was conducted on weeds in close proximity to the transplant as a result of intelligent weeding. Vander Weide et. al.,( 2008) showed that intelligent weeding method compared of cultivating the soil close to cabbage plants can provide satisfactory weed control without any need for subsequent manual weeding. Mechanical weeding practices such as weed cultivation, torsion weeding, brush weeding, and finger weeding have been studied for intra-row weed control in both directsown and transplanted Allium species, the weeding effectiveness is related to the stage of weed growth ,the avoidance of crop damage relies on operator skills and on conditions which is when crop plants are significantly more resistant to soil disturbance than weeds .

The objective of this study is to develop and evaluate new cultivator unit with modified share and press wheel suit for inter - row mechanic cultivation operation.

\section{MATERIALS AND METHODS}

This study was carried out to investigate the performance and operating parameters of a developed manufactured cultivator with modified share attached with press wheel for reshape inter-row profile, the cultivator provide with two protection wheel arm. 
Also this study aimed to choosing between performance of three different shapes of shares used with this cultivator suit for cultivation process in vegetables inter-row field lines with modified share.

The field experiments were conducted on the tomato crop variety sermpie in a field at El-Baramon village El- Dakahlia Governoratehe in a clay loam soil. The chemical and mechanical properties of the experimental soil are summarized in table (1).

Table (1): The mechanical analysis of the field soil.

\begin{tabular}{|c|c|c|c|c|}
\hline \multicolumn{4}{|c|}{ Particles size distribution (\%) } & \multirow{2}{*}{$\begin{array}{c}\text { Soil } \\
\text { Texture }\end{array}$} \\
\hline Clay & Silt & $\begin{array}{l}\text { Fine } \\
\text { sand }\end{array}$ & $\begin{array}{c}\text { Coarse } \\
\text { sand }\end{array}$ & \\
\hline 47.5 & 38.2 & 12.4 & 1.9 & Clay loam \\
\hline
\end{tabular}

\section{Tomato ridge describing:}

It is important to study and determine the dimensions of the tomato planting ridges and the distances between the cultivation inter-row distance as shown in fig. (1) to helped design and choose dimensions of the cultivator unit

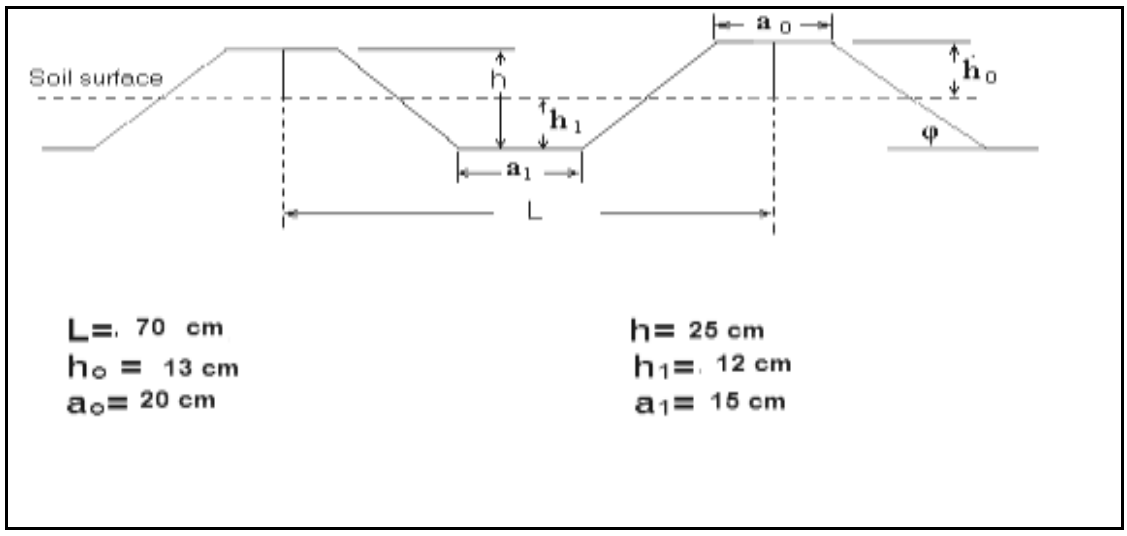

Fig. (1): General geometry of studied tomato ridge.

\section{The developed a cultivator unit:-}

The developed cultivator unit with modified parts was constructed and fabricated at the local workshop in Mansoura city, it's manufactured as proto-type one unit suitable for one inter-row cultivation process and consists of many parts as shown in fig. (2A and $2 \mathrm{~B})$ 

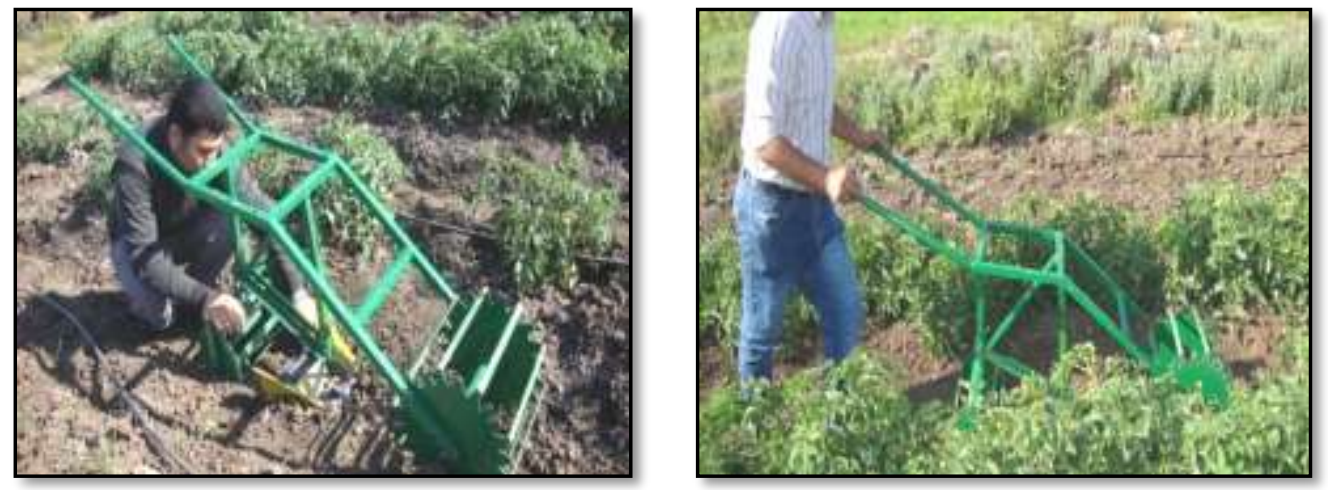

Fig. (2A): Cultivator unit during field experiments.

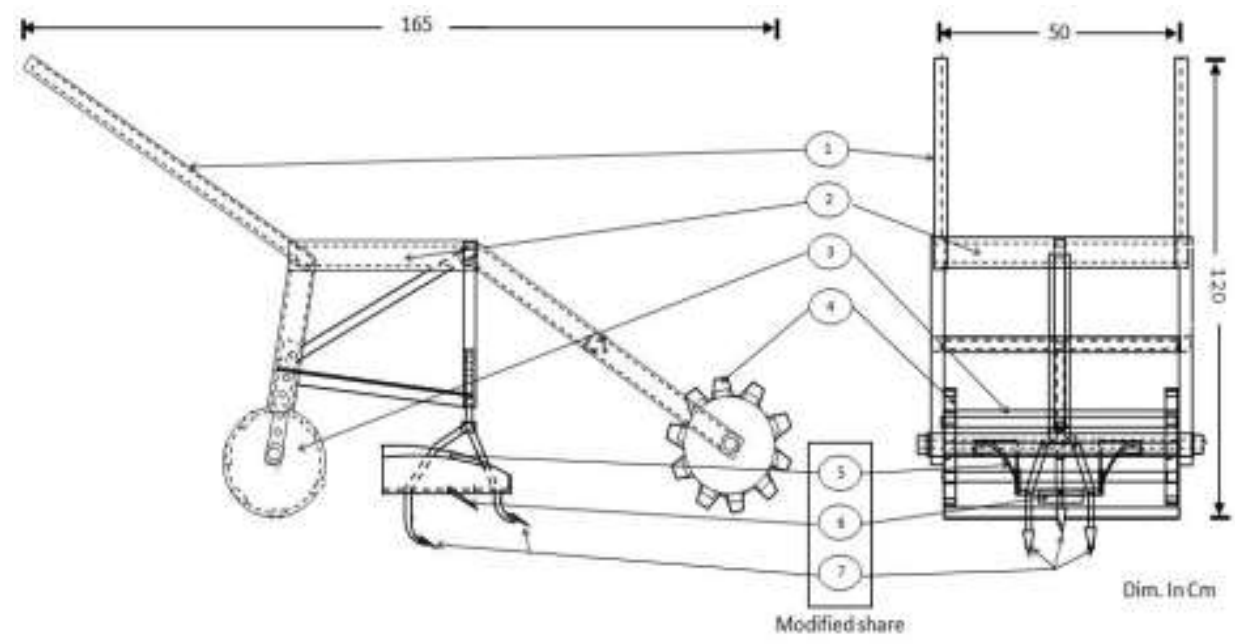

1) Cultivator payment arm. 2) Cultivator frame.

3) Press wheel.

4) Protection wheel arm.

5) Soil piling up wing.

6) Under surface cultivation shares.

7) Soil sliding knife.

Fig. (2B): A schematic diagram for developed cultivator unit with developed parts.

From fig. ( $2 \mathrm{~A}$ and $2 \mathrm{~B}$ ) the cultivator unit consists of four main parts as follow:

Cultivator frame : main chassis collecting parts of cultivator unit made of light iron bars with two bull arms in the front.

Protection wheel arm : At the front of the cultivator unit as a supporting and two side protection wheels for the sides of the planting ridge. 


\section{Modified share:}

The cultivator unit attached with new modified share, it consists of three main parts as shown in fig. (3)

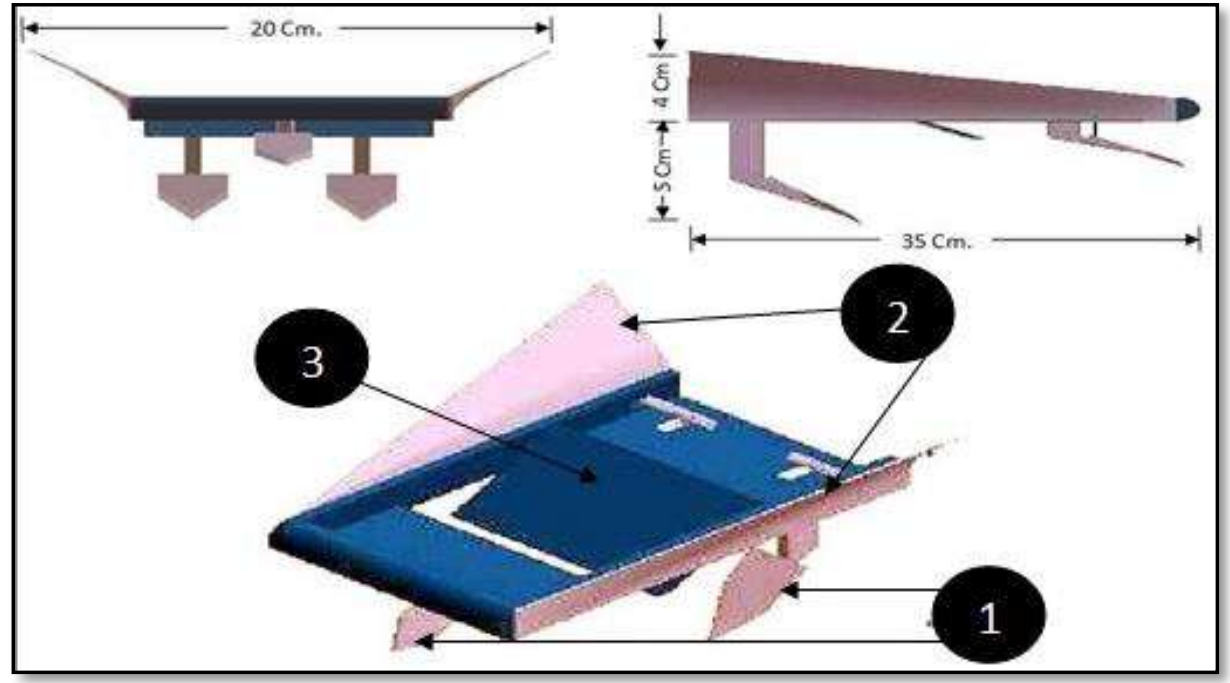

Fig. (3): Modified share parts with main dimensions.

(1) Under surface cultivation shares to disturb and dismantle the soil for good ventilation and improve the characteristics of drainage and weed defect.

(2) Soil piling up wing to collect and coordinate the soil on both sides of the planting ridge.

(3) Soil sliding knife $(15 \times 5 \mathrm{~cm})$ helped to dismantling the soil granules and cutting the root of weeds

Press wheel : a press wheel built- up in cultivator frame behind the modified cultivator share for the purpose of reshaping the bottom and sides of inter-row furrow profile.

\section{Scope of factors:-}

The main studied factors used in field experiments were as follows:-

1-Three types of shares used in cultivator unit St (shovel share \& Duck leg share \& modified share with wings)

2- Four inclination angles of soil sliding knife $\mathbf{S a}\left(\mathbf{S a} 1=30^{\circ} \& \mathbf{S a 2}=35^{\circ}\right.$ $\& \mathbf{S a 3}=40^{\circ} \& \mathbf{S a} 4=45^{\circ}$ )

3- Three depths of press wheel Wd $(W d 1=2 \& W d 2=3$ and $W d 3=4$ $\mathrm{cm}$.). 
There are two fixed factors (mean of labor generally forward speed ( $1 \pm$ $0.06 \mathrm{~m} / \mathrm{s}$ ) and depth of cultivating shares at $5 \mathrm{~cm}$ )

\section{Experimental measurements:}

There were four measurements were calculated as follows:

1- Weed erasing efficiency (We \%) : The weed erasing efficiency intended is the number of weeds that already removed in the $15 \mathrm{~m}$. of the inter-row longitudinal distance, counted directly after cultivation process and estimating at different treatments under study by the following equation.

where:

$$
\mathrm{We} \%=\left(1-\frac{R_{1}}{R}\right) \times 100
$$

$\mathbf{R}_{\mathbf{1}}=$ Number of stay weeds directly after cultivation.

$\mathbf{R}=$ Total number of weeds .

2- Weed control efficiency (Wc \%) : The weed control efficiency intended is the number of weeds that already removed in the $15 \mathrm{~m}$. of the inter-row, counted after 10 days from cultivation process and irrigation and estimating at different treatments under study by the following equation.

\section{where:}

$$
\mathbf{W c} \%=\left(1-\frac{R_{2}}{R}\right) \times 100
$$

$\mathbf{R}_{\mathbf{2}}=$ Number of weeds that already stay after 10 days from cultivation process and irrigation in $15 \mathrm{~m}$ longitudinal distance from inter-row.

3- Percentage of damaged plants (Dp \%) : The percentage of damaged tomato plants intended the number of plants that are damaged from passing the cultivator unit, estimated for same factors under study by the following equation.

where:

$$
\mathbf{D} \mathbf{p} \%=\left(1-\frac{N_{d}}{N_{p}}\right) \times 100
$$

$\mathbf{N}_{\mathbf{d}}=$ Number of undamaged plants.

$\mathbf{N}_{\mathbf{p}}=$ The total number of growing plants before passing of cultivator

4- Furrow profiles (Fp) : The ordinates and furrow cross - section profiles were measured and draw after each pass of cultivator unit with modified share by using the profile-meter shown in Fig. (4) 


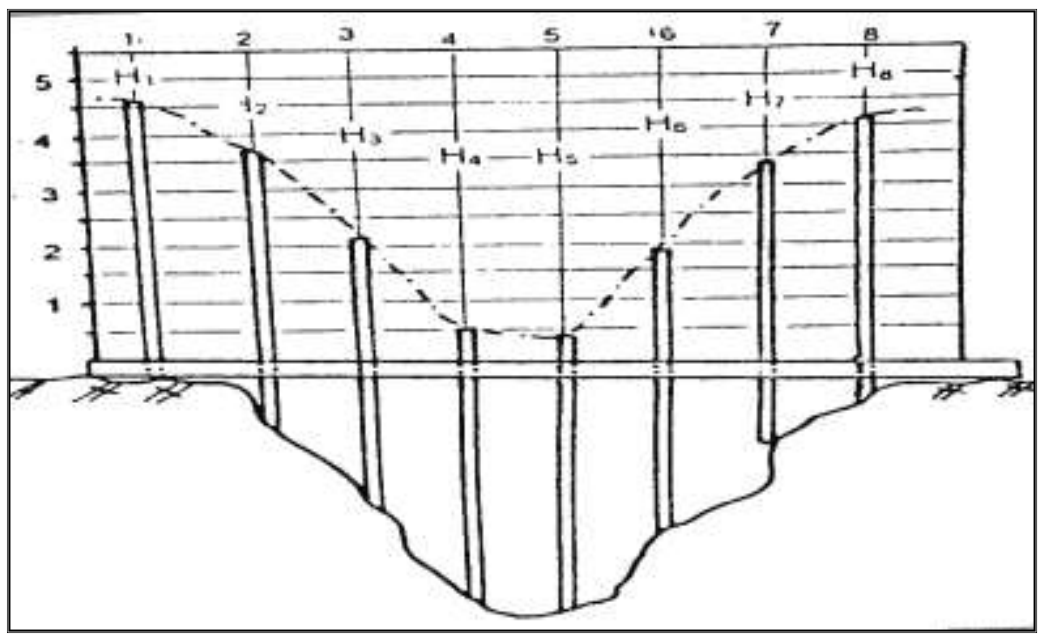

Fig. (4): The profile-meter used for determine the furrow profile of inter - row planting ridge.

\section{RESULTS AND DISCUSSION \\ 1- Weed erasing efficiency (We \%)}

Fig. 5 (A to D) show that, the highest value of weed erasing efficiency 97\% obtained by using cultivator unit with wing share at highest press wheel depth $(\mathrm{Wd} 3=4 \mathrm{~cm})$ with soil sliding knife inclined angle $(\mathrm{Sa}=$ $45^{\circ}$ ), the lowest value of weed erasing efficiency $78 \%$ obtained by using developed cultivator unit with shovel share at lowest press wheel depth $(\mathrm{Wd} 1=2 \mathrm{~cm})$ with soil sliding knife inclined angle $\left(\mathrm{Sa}=30^{\circ}\right)$, the highest value of weed erasing efficiency $\%$ mean that the highest number of weeds that already erasing obtained with wing share, due to its wide enough to erase and cut weeds roots under the soil more than another types of shares.

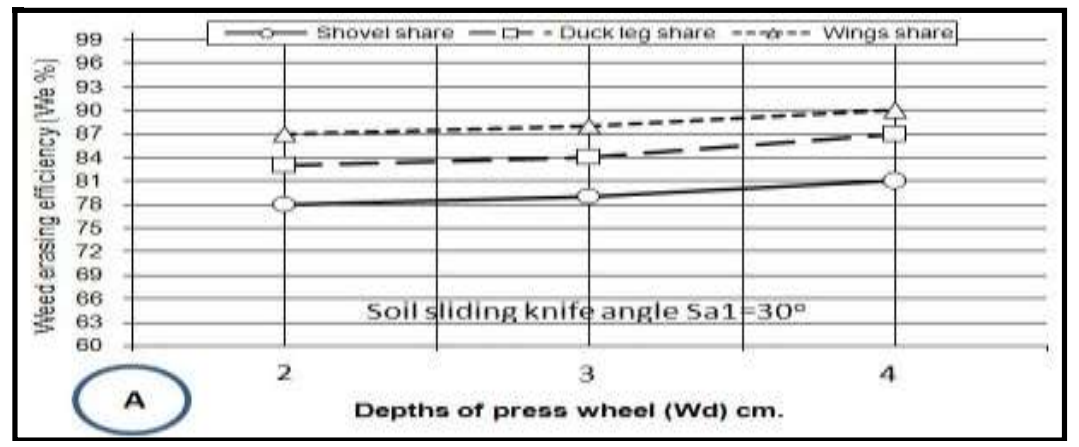




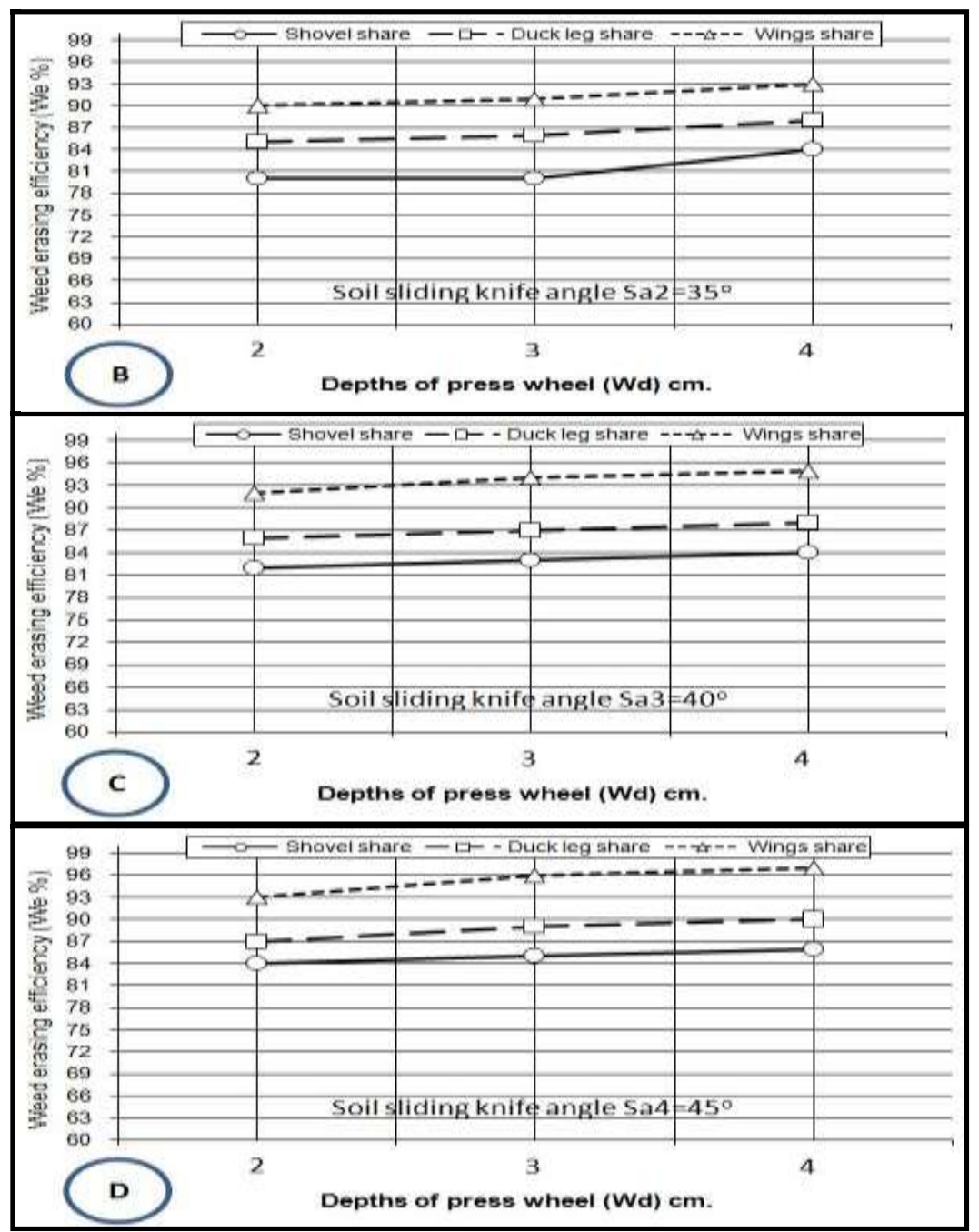

Figs. 5 (A to D): Weed erasing efficiency (We\%) at three levels of cultivator press wheel depths $(\mathrm{Wd}) \mathrm{cm}$, and inclined angles of soil sliding knife $\left(\mathrm{Sa}^{\circ}\right)$ with different types of shares treatments.

\section{2- Weed control efficiency (Wc \%) :}

From figs. 6 (A to D) the highest value of weed control efficiency $91.8 \%$ in row after 10 days from cultivation process and irrigation was obtained by using cultivator unit with wing share at highest press wheel depth $(\mathrm{Wd} 3=4 \mathrm{~cm})$ with soil sliding knife inclined angle $\left(\mathrm{Sa}=45^{\circ}\right)$, the lowest value of weed control efficiency $70.2 \%$ by using developed cultivator unit with shovel share at lowest press wheel depth $(\mathrm{Wd} 1=2 \mathrm{~cm})$ with soil sliding knife inclined angle $\left(\mathrm{Sa}=30^{\circ}\right)$ this due to, using developed 
cultivator with wing share erased the highest number of weeds and soil sliding knife cut weeds roots, with maximum press wheel depth because of modified share can cut roots of weeds that led to erasing of weeds, this explain remaining the lowest number of weeds in inter - row.
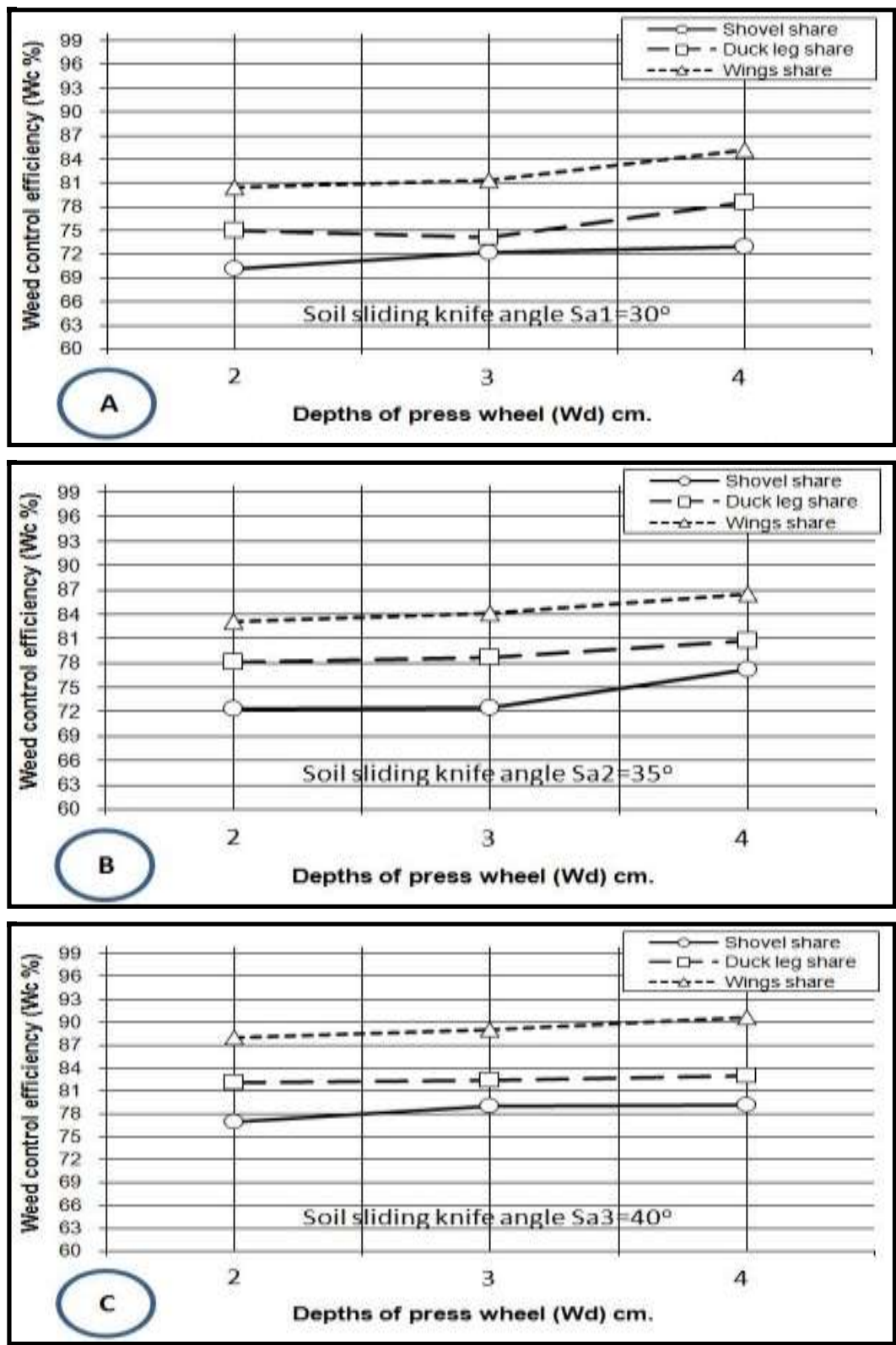


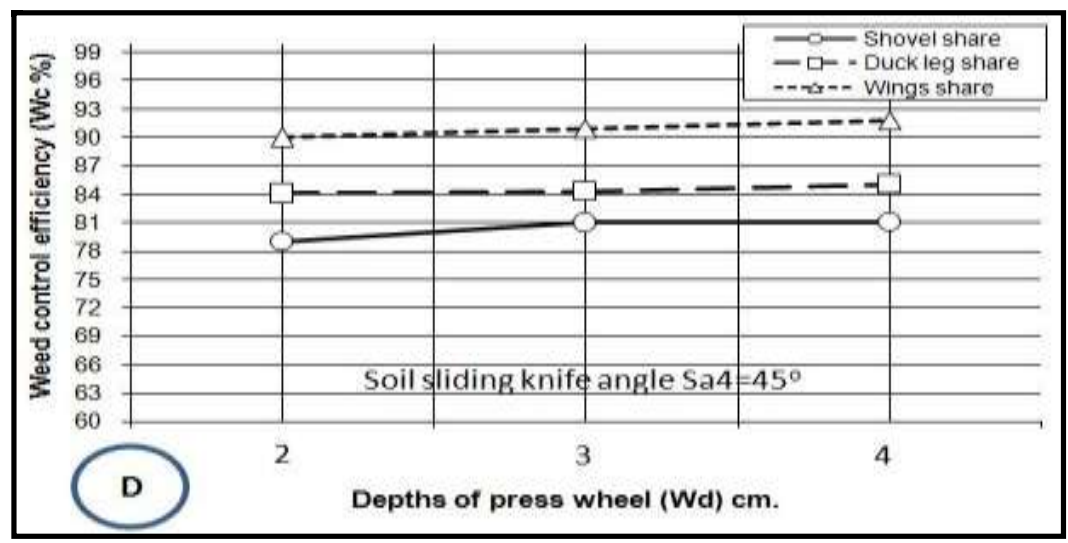

Figs. 6 (A to D): Weed control efficiency (Wc\%) at three levels of cultivator press wheel depths $(\mathrm{Wd}) \mathrm{cm}$, and inclined angles of soil sliding knife $\left(\mathrm{Sa}^{\circ}\right)$ with different types of shares treatments.

\section{3- Percentage of damaged plants (Dp \%)}

Data demonstrated in figs. 7 (A to D) show that the highest damage plant percentage $(1.2 \%)$ was obtained with used cultivator unit with duck leg share at highest cultivator press wheel depth $(\mathrm{d} 3=4 \mathrm{~cm})$ and soil sliding knife inclined angle $\left(\mathrm{Sa}=30^{\circ}\right.$ ), on the other hand from previous demonstrated data the lowest values of plant damage $(0 \%)$ was obtained with shovel share in developed cultivator unit at lowest cultivator press wheel depth $(\mathrm{Wd} 1=2 \mathrm{~cm})$ and soil sliding knife inclined angle $(\mathrm{Sa}=$ $45^{\circ}$ ), one can notice that, the cultivator unit with protection wheel armors protected plants to be damaged and shovel share is width-less than duck leg share used in experimental study which have less damage of plants in rows also a less efficiency in removing weeds.

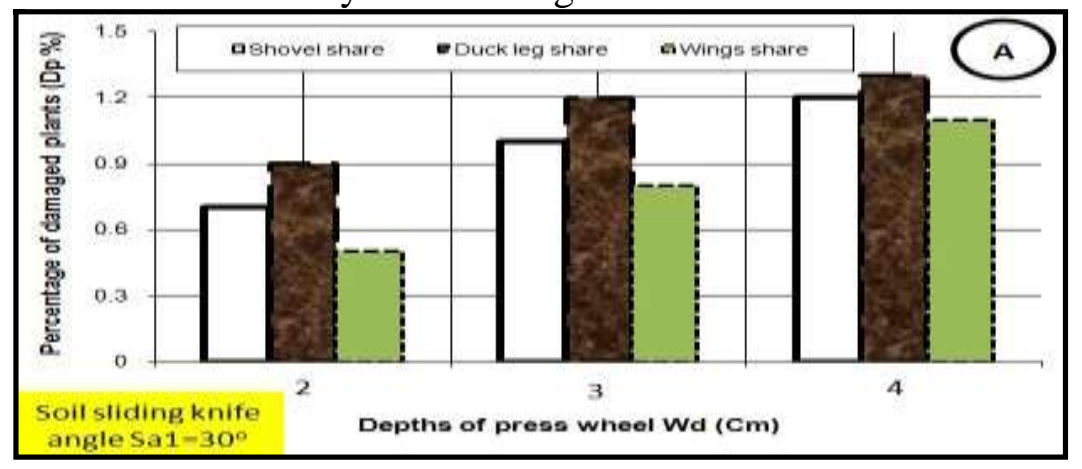



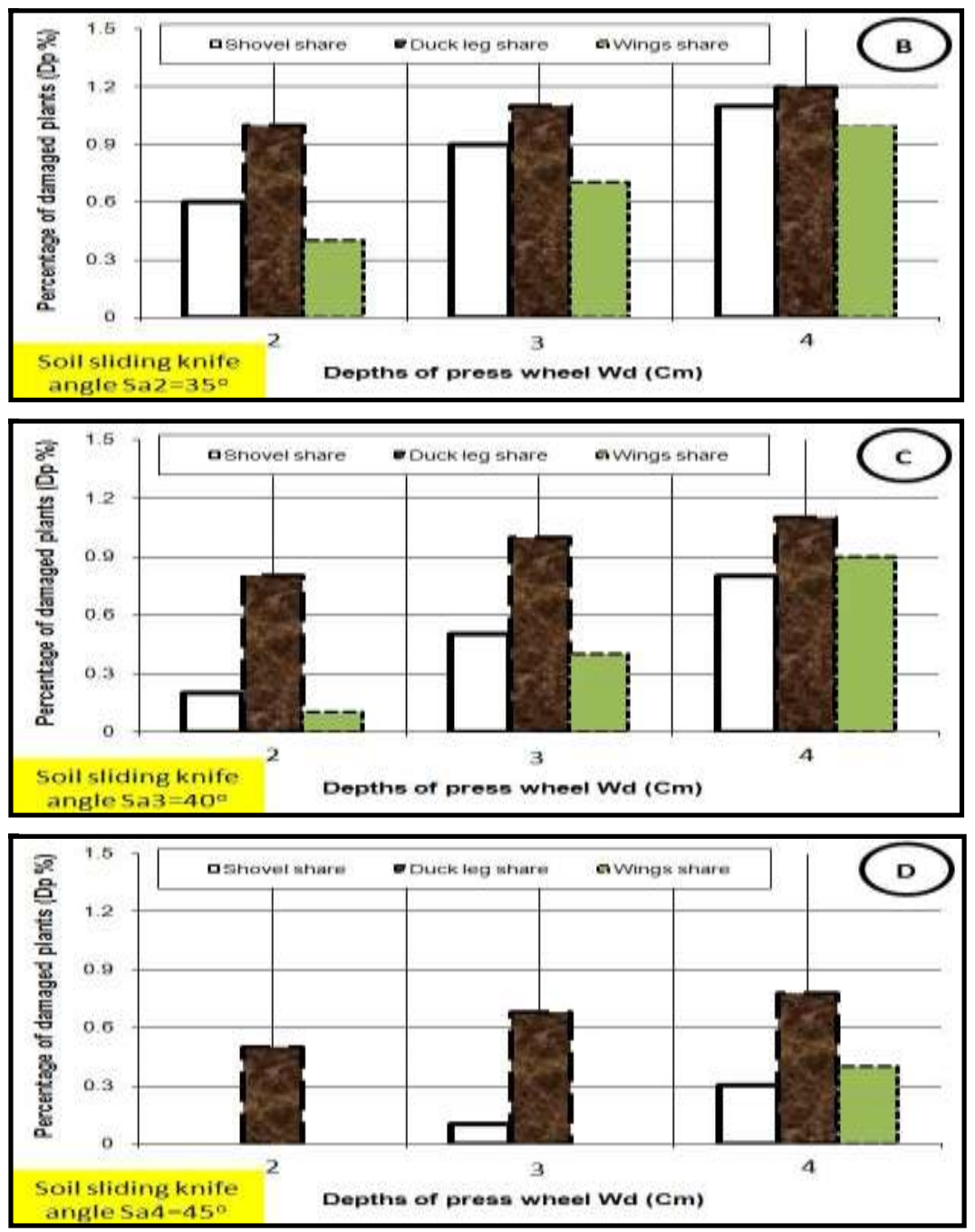

Figs. 7 (A to D): Damaged plants percentage (Dp\%) at three levels of cultivator press wheel depths (Wd) cm, and inclined angles of soil sliding knife $\left(\mathrm{Sa}^{\mathbf{}}\right)$ with different types of shares treatments.

\section{4) Furrow profiles}

From data mentioned in figs. 8 (A to $\mathrm{C}$ ) one can said that the press wheel contributed to furrow profiles to be more regular with all treatments under study, from the other hand the optimum Furrow profiles achieved with wing share at highest press wheel depth $(\mathrm{Wd} 3=4 \mathrm{~cm})$, from previous data one could noticed that, the inclination angles of soil sliding knife $\left(\mathrm{Sa}=45^{\circ}\right)$ had positive effect on all the results obtained so the 
furrow profiles were drawn at this angle to illustrate the effect of the others treatments on the uniformity of the profile. from data were graphically in figs. 8 (A to $\mathrm{C}$ ) we can see clearly the bottom of furrow and ridge side profiles to be more regular with increment of cultivator press wheel depth also using protection wheel this may be led to positive affecting on furrow sides shapes, from the other hand, used wing share let furrow bottom surface more stable and regular.
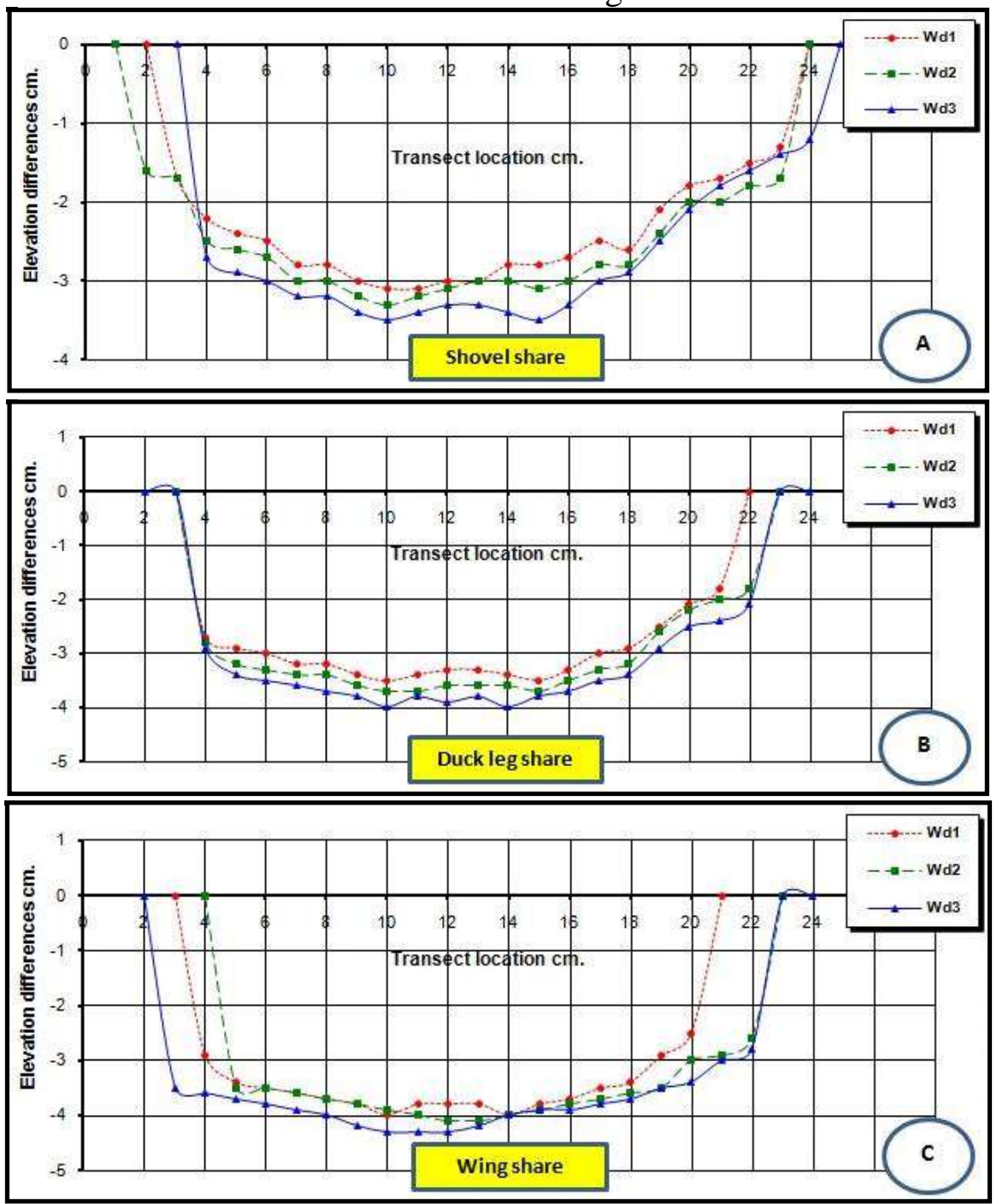

Figs. 8 (A to C). The furrow cross - section profiles at three levels of cultivator press wheel depths (Wd) for different types of shares treatments and inclined angle of soil sliding knife $\left(\mathrm{Sa}=\mathbf{4 5}^{\circ}\right)$ 


\section{CONCLUSION}

This study showed good performance of developed cultivator unit on weed control and inter- row furrow profile shape. The most important results of this study were explained that the highest press wheel depth $(\mathrm{Wd} 3=4 \mathrm{~cm})$ with soil sliding knife inclined angle $(\mathrm{Sa}=45 \mathrm{o})$ and wing share obtained high erasing efficiency $(\mathrm{We}=97 \%)$ and highest weed control with regular forming furrow profile, on the other hand duck leg share had highest damage plant percentage $(\mathrm{Dp}=1.2 \%)$. It is advised to use mechanical integrated cultivation process especially with crop plants, integrated cultivator can be developed as multi inter-rows (four rows as minimum) attached and trailed behind the tractor.

\section{REFERENCES}

Amonov, M. O.; Pulatov, T. S. and Colvin, T. S. (2006) Machine innovation for inter row cotton cultivation in Uzbakistan. American Society of Agricultural and Biological Engineers ISSN 0883-8542. Vol. 22(5): 665-674.

Euro, P. and Francesco, T. (2014) Effects of mechanical and chemical methods on weed control, weed seed rain and crop yield in maize, soyabean. Science direct crop protection 64,51-59.

Harker, K.N. and O'Donovan, J.T. (2013) Recent weed control, weed management, and integrated weed management. Weed Technol. 27, $1-11$.

Mahilang, K.K.S.; Choudhary, S.; Victor, V.M. and Sonboier, K.K. (2017). Design and development of power operated rotary weeder for rice. Current Journal of Applied Science and Technology, 24(5), 1-7.

Manuwa, S.I.; Odubanjo, O.O.; Olofinkua, S.G. and Malumi, B.O. (2009). Development and performance evaluation of a row-crop mechanical weeder. Journal of Engineering and Applied Science, 4(4), 236-239. 
Melander, B.; Rasmussen, I.A. and Barberi, P. (2005). Integrating physical and cultural methods of weed control-examples from European research. Weed Sci. 53, 369-381.

Pannacci, E. and Tei, F. (2014). Effects of mechanical and chemical methods on weed control, weed seed rain and crop yield in maize, sunflower and soyabean. Crop Prot. 64, 51-59.

Rathod, R.K.; Munde P.A. and Nadre, R.G. (2010). Development of tractor drawn inter-row rotary weeder. International journal of Agricultural Engineering, 3(1), 105-109.

Srinivas, I.; R.V. Adake; B. Sanjeeva Reddy; G.R. Korwar and Thyagaraj, C.R. (2008). Innovation in mechanical weed control in crop rows. WeedRes. 48, 215-224.

Vander Weide, R.Y., Bleeker, P.O., Achten, V.T.J.M., Lotz, L.A.P., Fogelberg, F. and Melander, B. (2008). Innovation in mechanical weed control in crop rows. Weed Res. 48, 215-224.

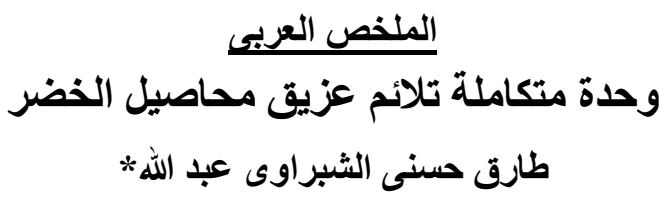

تعتبر عملية العزيق الميكانيكى من العمليات الزراعية الهامة و الدقيقة للحفاظ على المحصول

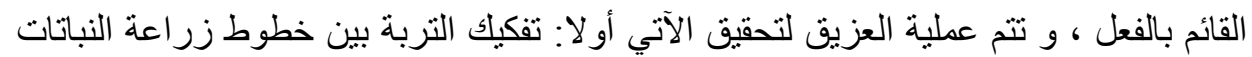

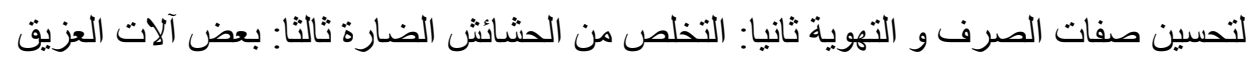

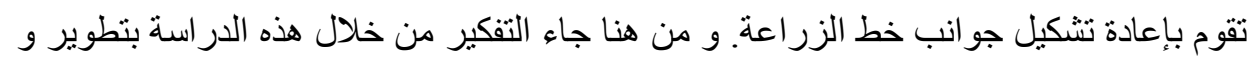

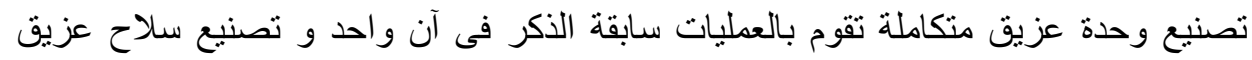

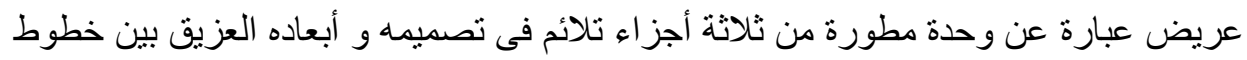

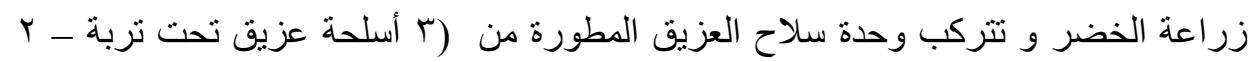

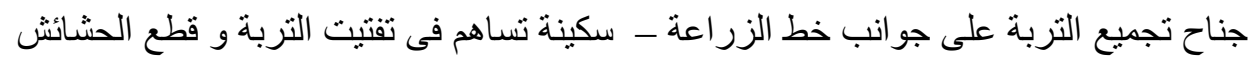

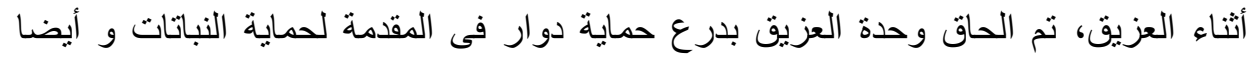

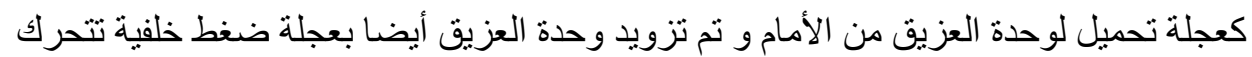
خلف وحدة سلاح العزيق مباشرة تساعد على اعادة تشكيل بطن الخطو أيضا تعمل كعجلة اسناد

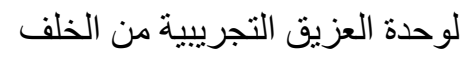

*أستاذ الهندسة الزراعية المساعد ـ كلية الزراعة - جامعة المنصورة 


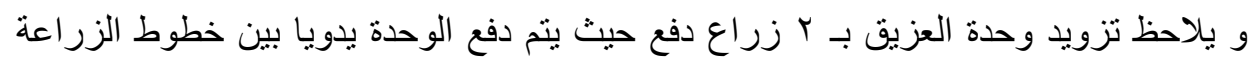

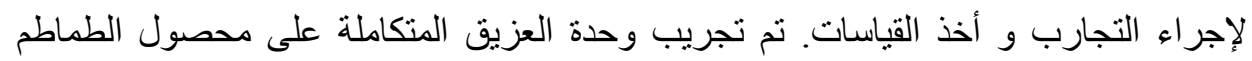

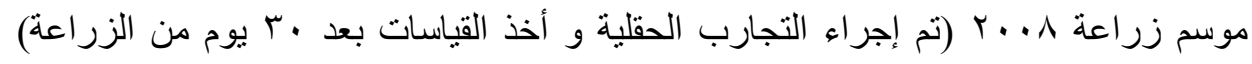

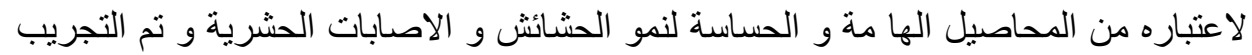

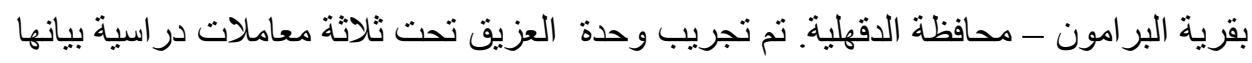

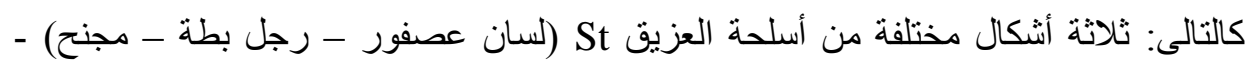

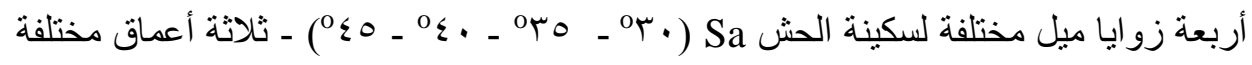

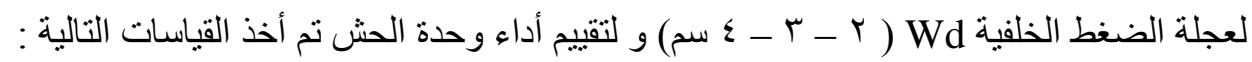

كفاءة إز الة الحشائش We\% - كفاءة نمو الحشائش Wc\% - نسبة التلف فى النباتات

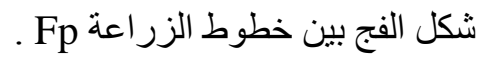

وأوضحت نتائج هذه الدراسة أن إستخدام وحدة العزيق المطورة كان لها دور فعال فى مكافحة

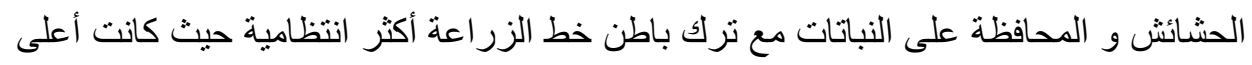

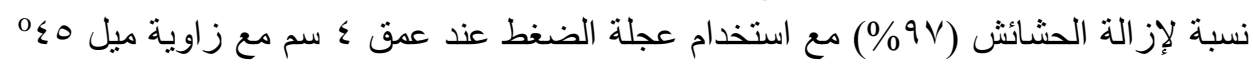

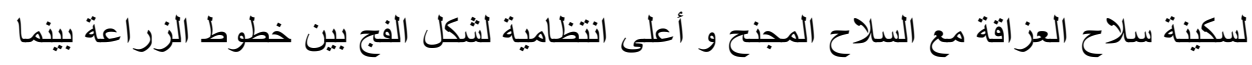

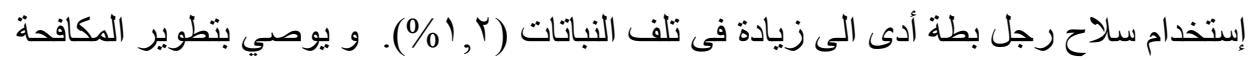

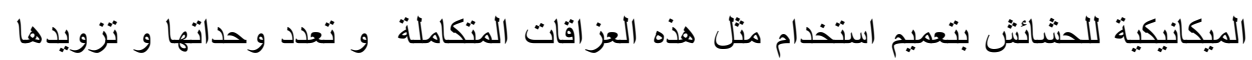
بنظام شبك و تجر خلف الجرار الزراعى. 